\title{
An Obscure Case of Hepatic Subcapsular Hematoma
}

\author{
Albert Ndzengue Fadi Hammoudeh Pierre Brutus \\ Ofem Ajah Roland Purcell Joseph Leadon \\ Richard B. Rafal Simon Balmir Danilo A. Enriquez \\ Gerald L. Posner Eric A. Jaffe Pradeep Chandra \\ Department of Medicine, Interfaith Medical Center, Brooklyn, N.Y., USA
}

\section{Key Words}

Liver · Hemorrhage · Coagulopathy

\begin{abstract}
Spontaneous liver bleeding is often reported in preeclampsia. It is otherwise rare and has been linked to gross anatomical lesions and coagulopathy. We report a case of subcapsular hematoma of the liver without any apparent lesion and in the absence of coagulopathy. A 41-year-old male, paraplegic for 16 years, presented to the emergency department 3 days after sudden onset of right upper quadrant and shoulder pain. He had been on vitamins and 5,000 units subcutaneous heparin 12-hourly at the nursing home for the last month. He was in no distress, afebrile, with stable vitals. Physical examination showed a diverting colostomy, tender hepatomegaly and sacral decubiti. A fecal occult blood test was negative. There was spastic paraplegia below the level of T12. Two days after admission, the patient was afebrile and hemodynamically stable. PTT, PT, liver profile, BUN and creatinine were all normal, however his hemoglobin had dropped from 11.3 to $7.6 \mathrm{~g} / \mathrm{dl}$. An abdominal CT scan revealed an isolated $9.0 \times 1.8 \mathrm{~cm}$ subcapsular hematoma. The patient received blood transfusion in the intensive care unit and was discharged 7 days later. In conclusion, spontaneous liver hemorrhage occurs in the nonobstetrical population in the setting of gross anatomical lesions or coagulopathy. This is the first report of an isolated subcapsular liver hematoma.
\end{abstract}

\section{Introduction}

Liver bleeding in the absence of trauma has been linked to gross anatomical lesions. We report a case of spontaneous subcapsular hematoma of the liver without any apparent lesion and in the absence of coagulopathy. 


\begin{tabular}{|c|c|c|c|}
\hline $\begin{array}{r}\text { Case Reports in } \\
\text { castroenterolowy }\end{array}$ & $\begin{array}{l}\text { Case Rep Gastroenterol 2011;5:223-226 } \\
\text { DOI: } 10.1159 / 000326998\end{array}$ & $\begin{array}{l}\text { Published online: } \\
\text { April 13, } 2011\end{array}$ & \begin{tabular}{|l} 
(@) 2011 S. Karger AG, Basel \\
ISSN $1662-0631$ \\
www.karger.com/crg
\end{tabular} \\
\hline
\end{tabular}

\section{Case Report}

A 41-year-old African-American male, paraplegic from a gunshot wound for 16 years, presented to the emergency room 3 days after sudden onset of dyspnea, right upper quadrant, shoulder and neck cramping pain worsened by body movements, and a tender mass in the right flank. The patient denied fever and acute anemia symptoms. He had been on vitamins, zinc sulfate, oxybutinin, and 5,000 units subcutaneous heparin 12-hourly at the nursing home for the last month. He tested negative for HIV and hepatitis $\mathrm{B}$ and $\mathrm{C}$ and denied using anabolic steroids. The patient was in no distress, afebrile, and had a pulse rate of 101 and a blood pressure of $130 / 85 \mathrm{~mm} \mathrm{Hg}$. On physical examination, no pallor or jaundice was noted. There was tenderness over the right trapezius muscle. Examination of the heart and lungs was normal. Mildly tender hepatomegaly was noted on a nondistended abdomen. A fecal occult blood test was negative. Stage 3 sacral decubiti, a functioning diverting colostomy, and an indwelling urinary catheter were present. There was complete spastic paraplegia below the level of T12. Laboratory results showed a hemoglobin of $11.3 \mathrm{~g} / \mathrm{dl}$, a white blood cell count of $9,500 / \mu \mathrm{l}$ and a platelet count of $248,000 / \mu \mathrm{l}$. PTT and PT were 28 and $12 \mathrm{~s}$, respectively. BUN, creatinine and liver profile were normal. Urinalysis was remarkable for leukocyte esterase and protein. The patient was started on ibuprofen, intravenous fluid and Unasyn to treat his infected decubiti and urinary tract infection.

Radiographs of the cervical spine and right shoulder were normal. A chest radiograph was unremarkable except for a bullet fragment overlying the left hemidiaphragm. A sonogram of the abdomen revealed a large liver $20 \mathrm{~cm}$ in height with an inhomogeneous ultrasound pattern suggestive of fluid accumulation.

Two days after admission, the patient was afebrile and hemodynamically stable with a mean pulse rate 85 and a mean arterial pressure of $103 \mathrm{~mm} \mathrm{Hg}$. However, he complained of persistent unchanged right shoulder pain. His hemoglobin had dropped to $7.6 \mathrm{~g} / \mathrm{dl}$. Two units of packed red blood cells were infused. An abdominal CT scan revealed a $9.0 \times 1.8 \mathrm{~cm}$ inhomogeneous, dense fluid collection causing a concave indentation upon the right lobe of the liver (fig. 1). A small amount of ascites was noted in the pelvis and lateral to the spleen. The patient was treated conservatively in the intensive care unit. Another 3 units of packed red blood cells were given over the next 2 days. The patient remained stable

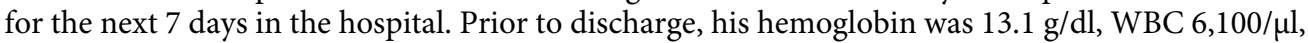

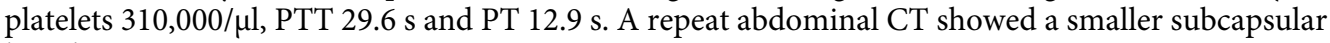
liver hematoma.

\section{Discussion}

A subcapsular hematoma of the liver is an accumulation of blood between Glisson's capsule and the liver parenchyma; rupture into the peritoneum has a $75 \%$ mortality rate $[1,2]$. The hematoma is usually located around the right lobe of the liver (in $75 \%$ of patients). Spontaneous subcapsular hematoma occurs in pregnancy and is mostly associated with preeclampsia and the HELLP syndrome [3-5]. Risk factors in the general population are hemodialysis, warfarin treatment, benign and malignant liver tumors, peliosis hepatis, periarteritis nodosa and hepatic adenomatosis [6-10].

Our case is unique in that none of the above risk factors were present. Subcutaneous heparin (5,000 units 8- to 12-hourly for thromboembolic disease prophylaxis) has not been linked to internal hemorrhage [11]. Our patient tested negative for HIV. He had no history of anabolic steroids use to be at risk for peliosis hepatis, and his CT was not suggestive of this entity [8].

Subcapsular hematomas of the liver progress in two phases [12, 13]. Rupture of the hematoma is typically associated with signs of hemodynamic collapse. In women, liver capsule distension associated pain along with nausea, vomiting, anorexia, dyspnea, and pallor are very suggestive of the diagnosis in late pregnancy. However, in a male the correct diagnosis is usually made by imaging or during explorative laparotomy. 


\begin{tabular}{c|l|l|l}
$\begin{aligned} \text { Case Reports in } \\
\text { Gastroenterology }\end{aligned}$ & $\begin{array}{l}\text { Case Rep Gastroenterol 2011;5:223-226 } \\
\text { DOl: 10.1159/000326998 }\end{array}$ & $\begin{array}{l}\text { Published online: } \\
\text { April 13, 2011 }\end{array}$ & $\begin{array}{l}\text { O 2011 S. Karger AG, Basel } \\
\text { ISSN 1662-0631 } \\
\text { www.karger.com/crg }\end{array}$ \\
\hline
\end{tabular}

CT better characterizes the fluid collection around the liver by determining its density and the presence of associated parenchymal hepatic lesions [14]. In our case, the high density of the fluid collection and the fall in hemoglobin without any exterior bleeding in a nonseptic patient suggested the diagnosis of a hematoma.

A contained hematoma in a stable patient is treated with fluid and/or blood transfusion $[12,13]$. Serial imaging and hematocrits are obtained while the patient is monitored in the intensive care unit to determine the hematoma is not progressing. The prognosis of a nonruptured subcapsular liver hematoma is good $[2,9]$, as demonstrated here. Surgery is reserved for cases of impending rupture or ruptured hematoma [12].

\section{Conclusion}

Spontaneous liver hemorrhage, although rare in the nonobstetrical population, should be considered in the differential diagnosis of sudden-onset abdominal pain radiating to the shoulder associated with hepatomegaly with or without signs of shock. This is the first reported case of subcapsular liver hematoma in the absence of gross anatomical lesions and coagulopathy.

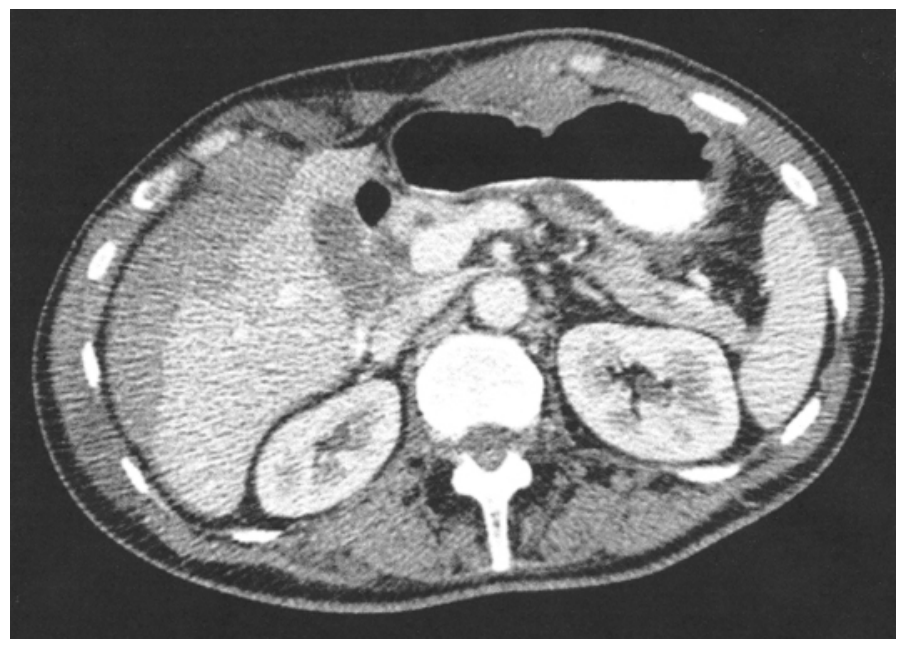

Fig. 1. CT of the abdomen/pelvis with intravenous contrast. Note the average density of 60 Hounsfield units for the fluid collection (subcapsular hematoma) by the right lobe of the liver; the liver density is about 80 Hounsfield units whereas the adjacent bile averages 29 Hounsfield units. 


\begin{tabular}{c|l|l|l}
$\begin{aligned} \text { Case Reports in } \\
\text { Gastroenterology }\end{aligned}$ & $\begin{array}{l}\text { Case Rep Gastroenterol 2011;5:223-226 } \\
\text { DOl: 10.1159/000326998 }\end{array}$ & $\begin{array}{l}\text { Published online: } \\
\text { April 13, 2011 }\end{array}$ & $\begin{array}{l}\text { O 2011 S. Karger AG, Basel } \\
\text { ISSN 1662-0631 } \\
\text { www.karger.com/crg }\end{array}$ \\
\hline
\end{tabular}

\section{References}

1 Bis KA, Waxman B: Rupture of the liver associated with pregnancy. A review of the literature and report of two cases. Obstet Gynecol Surg 1976;31:763-773.

2 Manas KJ, Welsh JD, Rankin RA, Miller DD: Hepatic hemorrhage without rupture in preeclampsia. N Engl J Med 1985;312:424-426.

3 Orea JG, Gavino I, Cardenas JL, Cuanalo A, Brachet S: Rupture of the liver and subcapsular hematoma caused by toxemia. A case successfully treated by left lobectomy. Ann Chir 1984;38:19-22.

-4 Sibai BM, Ramadan MK, Usta I, Salama M, Mercer BM, Friedman SA: Maternal morbidity and mortality in 442 pregnancies with hemolysis, elevated liver enzymes and low platelets (HELLP syndrome). Am J Obstet Gynecol 1993;169:1000-1006.

-5 Schwartz ML, Lien JM: Spontaneous liver hematoma in pregnancy not clearly associated with preeclampsia: a case presentation and literature review. Am J Obstet Gynecol 1997;176:1328-1332, discussion 1332-1333.

-6 Abi F, el Fares F, Berrada R, Boutaleb Y: Les lésions hépatiques hémorragiques de la toxLmie gravidique. J Chir (Paris) 1986;123:742-745.

7 Ulu EM, Uyuşur A, Ekici Y, Hunca Ç, Coşkun M: Multidetector CT findings of spontaneous rupture of hepatic adenoma in a patient with hepatic adenomatosis. Diagn Interv Radiol 2009;15:135-138.

8 Choi S, Jin J, Cho SG, et al: Spontaneous liver rupture in a patient with peliosis hepatis: a case report. World J Gastroenterol 2009;15:5493-5497.

-9 Behranwala KA, Tisdall M, Habib NH, Canelo R: Spontaneous bilobar subcapsular hematoma of the liver while undergoing anticoagulation therapy: our experience and review of the literature. Int Surg 2004;89:212-216.

10 Ueda K, Matsui H, Watanabe T, Seki J, Ichinohe T, Tsuji Y, Matsumura K, Sawai Y, Ida H, Ueda Y, Chiba T: Spontaneous rupture of liver plasmacytoma mimicking hepatocellular carcinoma. Intern Med 2010;49: 653-657.

-11 Manganelli D, Pazzagli M, Mazzantini D, Punzi G, Manca M, Vignali C, Palla A, Troiani R, Rossi G, Palla A: Prolonged prophylaxis with unfractioned heparin is effective to reduce delayed deep vein thrombosis in total hip replacement. Respiration 1998;65:369-374.

12 El Youssoufi S, Nsiri A, Salmi S, Miguil M: Liver rupture in peripartum: about 8 cases. J Gynecol Obstet Biol Reprod (Paris) 2007;36:57-61.

13 Santos-Bolivar J, Perozo-Romero J, Prieto-Montano J, Reyna-Villasmil E, Torres-Cepeda D: Rupture of hepatic subcapsular hematoma as a complication of HELLP syndrome. Cir Esp 2010;87:50-51.

14 Ben Aissa N, Battar S, Gara M, Bouhaja B, Ben Ammar MS: Hématome sous-capsulaire du foie complication de la prééclampsia. J Magh Anesth Reanim 2001;8:131-133. 